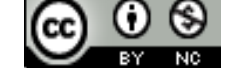

Jurnal Bimbingan Konseling Indonesia is licensed under A Creative Commons Attribution-Non Commercial 4.0 International License.

\title{
ANALISIS PERILAKU PROKRASTINASI AKADEMIK SISWA SMPS ABDI AGAPE SINGKAWANG
}

\author{
Nopita $^{1)}$, Dian Mayasari $^{2)}$, Insan Suwanto ${ }^{3)}$ \\ 1) Bimbingan Konseling, STKIP Singkawang, Indonesia \\ E-mail: novinovita39@ymail.com \\ ${ }^{2)}$ Bimbingan Konseling, STKIP Singkawang, Indonesia \\ E-mail: diansingkawang@gmail.com \\ 3) Bimbingan Konseling, STKIP Singkawang, Indonesia \\ E-mail:insansuwanto@gmail.com
}

\begin{abstract}
Abstrak. Penelitian ini bertujuan untuk mengetahui: 1) Perilaku prokrastinasi akademik siswa SMPS Abdi Agape Singkawang. 2) Penyebab terjadinya perilaku prokrastinasi siswa SMPS Abdi Agape Singkawang. Penelitian yang digunakan adalah penelitian deskiftif dengan pendekatan kualitatif. Subjek dalam penelitian adalah siswa SMPS Abdi Agape Singkawang yang melakukan perilaku prokrastinasi akademik. Objek dalam penelitian adalah perilaku prokrastinasi yang di lakukan siswa SMPS Abdi Agape Singkawang. Teknik pengumpulan data dalam penelitian ini mengunakan wawancara, pengamatan, dokumentasi. Berdasarkan hasil analisis data yang didapatkan dilapangan 1) Perilaku prokrastinasi akademik siswa adalah menunda memulai dan menyelesaikan tugas; siswa terlambat dalam mengumpulkan tugas; siswa lebih suka melakukan aktivitas lain yang menyenangkan seperti berbicara di kelas, menganggu teman di kelas, bermain game online. 2) Penyebab perilaku prokrastinasi akademik adalah siswa tidak mengerti penjelasan tugas yang diberikan guru; siswa tidak menyukai mata pelajaran tertentu seperti Ilmu Pengetahan Alam, Matematika, Bahasa Inggris, Bahasa indonesia, Ilmu Pengetahan Sosial; ikut-ikutan teman yang tidak mengerjakan tugas, motivasi belajar yang rendah.
\end{abstract}

Kata Kunci: Prokrastinasi; Siswa

\section{PENDAHULUAN}

Perkembangan dunia pendidikan semakin meningkat, dan mutu pendidikan juga menjadi acuan penting dalam menciptakan generasi yang bermutu. Semuanya bertujuan untuk menciptakan generasi muda yang memiliki daya pikir yang kreatif dan inovatif. Namun dalam pencapaian tujuan pendidikan memang tidak mudah untuk dicapai. Banyak faktor yang dapat menghambat kemajuan ini salah satunya adalah prokrastinasi. Prokrastinasi adalah suatu kegiatan penundaan yang di lakukan secara sukarela oleh siswa meskipun siswa tersebut sadar bahwa tindakanya akan berdampak pada aktivitas yang dijalankannya. Seperti menghadapi tugas-tugas penting (tugas primer) perilaku menunda akan selalu dilakukan bahkan sudah menjadi kebiasaan yang sulit untuk dihilangkan. Dalam lingkungan akademik, sebagian besar dari siswa telah mengakui mempunyai kecenderungan melakukan prokrastinasi yang pada akhirnya menimbulkan dampak negatif (Rohmatun \& Taufik, 2014). Memang sulit dimengerti perilaku prokrastinasi akademik kini sudah menjadi hal yang biasa ditemukan di sekolah-sekolah.

Tiga penyebab dasar seseorang melakukan perilaku prokrastinasi diantaranya: 1) Prokrastinasi pada suatu hal yang dianggap tidak menyenangkan: 
2) Prokrastinasi karena niat dalam diri yang rendah untuk menyelesaikan sesuatu; 3) Prokrastinasi dikarenakan mudah terganggu (tidak fokus). Perilaku prokrastinasi dapat di pengaruhi oleh beberapa hal salah satunya di pengaruhi oleh diri sendiri (Pychyl, 2014).

motivasi berprestasi dapat mempengaruhi prokrastinasi dengan membuat bekerja secara intrinsik (dari dalam diri) dan dengan demikian dapat mengurangi sesuatu yang dianggap tidak menyenangkan. Motivasi berprestasi tidak terbatas pada motivasi intrinsik, tetapi di dukung oleh motivasi ekstrinsik juga (Reza, 2015). Menyimpulkan bahwa individu dengan motivasi akademik yang positif menunjukkan karakteristik memiliki keinginan untuk belajar, suka kegiatan belajar terkait dan percaya bahwa sekolah itu penting (National Association of School Psychologists, 2014). Motivasi akademik yang positif tidak hanya membantu individu untuk melihat pembelajaran yang bermanfaat tetapi juga penting dalam semua aspek kehidupan dan masyarakat.

Dampak perilaku prokrastinasi akademik menurut Ferrari merupakan banyaknya waktu yang terbuang sia-sia, tugas-tugas jadi terbengkalai dan bila di selesaikan hasilnya menjadi tidak maksima (Munawaroh, Alhadi \& Saputra, 2017) Dalam penyelesaian suatu tugas memang sangat penting untuk memperhatikan waktu, karena dalam suatu tugas pasti ada batas yang diberikan untuk menyelesaikan dan mengumpulkannya.

Faktor prokrastinasi akademik terjadi karena ada dua faktor yaitu faktor internal dan juga faktor eksternal (Rosani \& Indrawati, 2018) . Faktor internal yaitu berasal dari diri siswa meliputi keperibadian dan rendahnya motivasi. Faktor eksternal yaitu faktor yang berasal dari luar siswa meliputi banyaknya tugas serta pola asuh orangtua. Seseorang yang memiliki motivasi rendah, biasanya akan lebih sering melakukan prokrastinasi akademik. Karena tidak ada keinginan yang mendorong siswa untuk mengerjakan tugas. Tugas yang terlalu banyak juga dapat menimbulkan perilaku prokrastinasi. Karena membuat siswa binggung untuk mengerjakan mana yang harus di kerjakan terlebih dahulu.
Faktor eksternal yang mendominasi terjadinya prokrastinasi salah satunya kontrol lingkungan yang rendah (Kuswandi, 2009). Seperti pola asuh orang tua yang terlalu longgar pada anak. Anak di biarkan untuk melakukan kegiatanya tanpa ada pengawasan dari orang tua. Orang tua yang bersifat acuh tak acuh terhadap prestasi anak. Selain pola asuh pengaruh teman sebaya juga dapat menjadi penyebab terjadinya prokrastinsai. Pada masa remaja siswa sudah belajar lebih madiri dan berhak menentukan keinginannya sendiri, namun tidak lepas dari kontrol orang tua. Siswa merasa kegiatan bersama teman sebaya lebih menyenangkan, dari pada berada dalam rumah dan belajar.

Faktor internal yang mendominasi perilaku prokrastinasi salah satunya karena pikiran irasional yang di miliki oleh siswa. Kesalahan dalam mempresepsikan tugas, siswa berpikir bahwa tugas yang di berikan guru sangat berat dan tidak menyenangkan. Prokrastinasi yang di lakukan dapat menimbulkan rasa takut berlebihan untuk gagal, siswa takut untuk menyelesaikan tugas dan sehingga berakibat pada penilaian yang negatif terhadap diri sendiri (Ramadhan \& Winata, 2016) .

Fenomena prokrastinasi akademik juga dapat menyebabkan penurunan produktivitas dan etos kerja siswa dalam mengerjakan tugas akademik sehingga membuat kualitas siswa menjadi rendah (Utomo, 2010) . Prokrastinasi akademik dalam jangka panjang cenderung membuat siswa menjadi seorang pembohong karena mereka akan membuat alasan untuk menghindari tugas-tugas akademik yang harus dikerjakan, tetapi hal ini berlaku pada tugas yang tidak disukai (Aziz, 2015) .

Seseorang dapat dikatakan sebagai prokrastinator ketika sudah memenuhi beberapa aspek penyebab terjadinya prokrastinasi akademik diantaranya, suka menunda untuk menyelesaikan tugas, kesenjangan waktu antara rencana kinerja yang aktual, melakukan aktifitas lain yang lebih menyenangkan (Santika \& Sawitri, 2016) .

Namun ada alasan mengapa seseorang tidak dapat dikatakan sebagai prokrastinator jika functional procrastination (penundaan mengerjakan tugas yang bertujuan untuk memperoleh informasi yang lebih lengkap dan akurat) (Saman, 2017). Siswa tidak memahami penjelasan guru mengenai 
materi pelajaran di kelas. Karena guru menjelaskan materi terlalu cepat atau suara guru terlalu lembut. Hal seperti ini biasanya terjadi ketika siswa diberi tugas berhitung, tugas praktek di labolatorium dan sebagainya. Sehingga pada saat guru memberikan tugas, siswa binggung untuk mengerjakanya. Untuk mendapatkan informasi yang lebih lengkap maka siswa harus bertanya kepada teman sekelas yang sudah mengerti atau kepada guru yang bersangkutan. Hal ini membuat siswa terlambat atau menunda sementara tugas yang diberikan guru. Tujuan dari penundaan yang di lakukan karena siswa kekurangan informasi.

\section{METODE}

Metode yang digunakan dalam penelitian ini adalah jenis deskriptif dengan pendekatan kualitatif. Penelitian kualitatif merupakan suatu strategi inquiry yang menekankan pencarian makna, pengertian, konsep, karakterisitik, gejala, simbol, maupun deskripsi tentang fenomena; fokus dan multimetode, bersifat alami dan holistik; mengutamakan kualitas, menggunakan beberapa cara, serta disajikan secara naratif. Dari sisi lain dan secara sederhana dapat dikatakan bahwa tujuan penelitian kualitatif adalah untuk menemukan jawaban terhadap suatu fenomena atau pertanyaan melalui aplikasi prosedur ilmiah secara sistematis dengan menggunakan pendekatan kualitatif (Moleong, 2017) .

Subjek penelitian ini adalah siswa SMPS Abdi Agape Singkawang berjumlah 4 orang. Subjek dipilih melalui pertimbangan tertentu misalnya, subjek paling tahu tentang apa yang peneliti harapkan. Pertimbangan bahwa subjek telah melakukan prokrastinasi menurut penjelasan wali kelas subjek. Pemilihan subjek diarahkan pada sumber data yang berhubungan langsung dengan permasalahan yang diteliti. Kemudian peneliti memilih subjek dengan teknik purposiv sampling karena dipandang lebih mampu menangkap kelengkapan dan kedalaman data dalam menghadapi realita yaitu teknik pengambilan sampel sumber data dengan pertimbanan tertentu (Yusuf, 2013).
Informasi dikumpulkan melalui beberapa instrumen pengumpulan data yaitu wawancara. Wawancara ini dibuat agar pembicaraan yang dilakukan dengan siswa terarah dan peneliti mendapatkan informasi yang jelas melalui pesan kata yang diungkapkan subjek. Dalam pedoman wawancara ada beberapa pertanyaan yang harus di tanyakan kepada subjek dan harus di jawab oleh subjek. Setiap pertanyaan dilakukan secara acak tidak berurutan sesuai suasana subjek. Pada saat melakukan wawancara peneliti melakukan wawancara secara santai agar subjek tidak merasa curiga kalau subjek sedang di teliti. Wawancara berlangsung dengan baik dan informasi pun dikumpulkan tanpa di ketahui oleh subjek.

Pengamatan dilakukan agar peneliti melihat secara langsung apakah, informasi yang di dapatkan melalui wawancara memang benar terjadi. Peneliti mencatat beberapa informasi yang berhubungan dengan perilaku yang ditunjukan subjek. Pada saat melakukan pengamatan peneliti melakukan pengamatan tidak terstruktur, karena kejadiankejadian tidak selalu berurutan atau terjadi secara acak dan alami. Pengamatan dilakukan pada saat subjek melakukan kegiatan belajar mengajar di kelas.

Dokumentasi adalah pelengkap informasi berikutnya agar informasi semakin jelas. Pada saat dokumentasi peneliti mengambil gambar kegiatan belajar mengajar di kelas secara diam-diam atau rahasia. Hal ini dilakukan agar tidak menganggu pengambilan informasi mengenai perilaku prokrastinasi subjek. Bukti dari dokumentasi yaitu foto kegiatan belajar dan juga absensi subjek.

Kemudian setelah informasi didapatkan maka peneliti melakukan olah data melalui organisasi data. Pada tahap ini peneliti mencatat semua informasi yang sudah didapatkan dilapangan agar proses analisis data lebih mudah. Terus peneliti melakukan pengkodean untuk mengelompokan setiap informasi sebelum di beri makna. Setelah di kelompokan maka peneliti melakukan akan memberikan makna dari setiap hasil dari wawancara, pengamatan dan dokumentasi. Tahap terakhir peneliti melakukan interpretasi data. Pada tahap ini peneliti harus berfikir kritis dan logis untuk memecahkan masalah, merencanakan 
penelitian, melakukan penelitian, mengumpulkan dan menganalisis sampai menarik kesimpulan kejadian di lapangan.

\section{HASIL DAN PEMBAHASAN}

Pada penelitian ini, peneliti megunakan analisis data kualitatif untuk mengetahui perilaku dan penyebab perilaku prokrastinasi akademik siswa SMPS Abdi Agape Singkawang. Hasil penelitian ini merupakan penelitian deskriftif kualitatif dengan subjek 4 orang siswa SMPS Abdi Agape Singkawang. Tujuan dari penelitian ini adalah untuk mengetahui perilaku prokrastinasi akademik dan penyebab terjadinya perilaku prokrastinasi akademik siswa. Pengolahan data melalui organisasi data, pengkodean data.

Berdasarkan hasil penelitian, perilaku dan penyebab prokrastinasi akademik adalah penundaan memulai mengerejakan dan menyelesaikan tugas. Siswa dikatakan memiliki perilaku prokrastinasi karena siswa sering melakukan prokrastinasi terhadap beberapa mata pelajaran yang dianggap tidak menyenangkan. Siswa hampir selalu melakukan perilaku prokrastinasi pada saat mata pelajaran dan guru tertentu.

Menurut Ferarri \& McCown perilaku prokrastinasi adalah kebiasaan atau pola perilaku yang berhubungan dengan trait penundaan merupakan suatu respon yang sering dilakukan oleh siswa saat menghadapi tugas dan disertai dengan keyakinan yang irasional (Burhani, 2016). Siswa memiliki perilaku prokrastinasi karena siswa sering melakukan perilaku prokrastinasi akademik terhadap beberapa mata pelajaran yang dianggap tidak menyenangkan. Perilaku prokrastinasi dapat menghasilkan keadaan emosional yang tidak menyenangkan, misalnya perasaan cemas, perasaan bersalah, marah, panik, dan sebagainya (Burhani, 2016).

Perilaku prokrastinasi akademik siswa dapat di sebabkan oleh pola hidup dan keyakinan yang irasional terhadap tugas yang diberikan guru tanpa memikirkan tujuan dan maksud dari tugas tersebut. Akibat perilaku menunda yang dilakukan siswa adalah perasaan yang tidak nyaman, rasa ingin marah pada diri sendiri, rasa panik karena batas pengerjaan tugas sudah beakhir. Sehingga pada saat siswa mengerjakan tugas hasilnya pun tidak maksimal, dan tidak sesuai dengan keinginan yang ingin dicapai. Ferrari dan Morales Mengungkapkan prokrastinasi akademik memberikan dampak yang negatif bagi para siswa, yaitu banyaknya waktu yang terbuang tanpa menghasilkan sesuatu yang berguna (Kadi, 2016)

Siswa SMPS Abdi Agape Singkawang sering terlambat dalam mengumpulkan tugas. Jenis perilaku prokrastinasi yang di lakukan siswa SMPS Abdi Agape Singkawang adalah penundaan tugas dengan guru dan mata pelajaran tertentu. Siswa yang memiliki perilaku prokrastinasi akademik adalah siswa yang memiliki etos kerja yang rendah karena siswa tidak memiliki kemampuan mengontrol diri dari hal-hal yang dapat membuat siswa menunda tugas (Utomo, 2010).

Menurut Watson anteseden prokrastinasi berkaitan dengan takut gagal, tidak suka pada tugas-tugas yang diberikan, menentang dan melawan kontrol, mempunyai sifat ketergantungan dan kesulitan dalam membuat keputusan (Burhani, 2016). Menurut Michelle siswa mengalami stress dan cemas akibat kesulitan-kesulitan dalam pengerjaan tugas, ketakutan menghadapi guru, jenuh, malas dan lain-lain. keterlambatan dalam menyelesaikan tugas yang diberikan guru adalah karena siswa merasa takut gagal (Srantih, 2014).

Hal ini biasa terjadi karena siswa tidak mengerti bagai mana harus mengerjakan tugas tersebut, karena siswa malas bertanya untuk kejelasan tugas yang diberikan, sehingga siswa merasa kesulitan saat hendak mengerjakan tugas, jadi siswa memilih untuk menunda mengerjakan sehingga siswa terlambat mengumpulkan tugas. Kesulitan-kesulitan yang dialami siswa semakin membuat siswa merasa stress dan cemas sehingga siswa tidak dapat mengontrol diri, kemudian timbulah rasa jenuh akan tugas-tugas. Bisa juga di sebabkan oleh perilaku guru yang tidak menyenangkan seperti jika siswa salah dalam mengerjakan tugas guru menghukum.

Siswa lebih suka melakukan aktivitas lain yang menyenangkan seperti berbicara di kelas, menganggu teman di kelas, bermain game online. Ferrari mengatakan bahwa siswa lebih suka 
melakukan aktivitas yang lebih menyenangkan (Saman, 2017). Prokrastinasi adalah suatu kecenderungan untuk menunda dalam memulai maupun menyelesaikan pekerjaan secara keseluruhan, tetapi melakukan aktivitas lain yang tidak berguna (Azar, 2014). Bahwa prokrastinasi adalah ketidak mampuan siswa dalam mengelola dan memanfaatkan waktu (Saman, 2017).

Burka dan Yuen menjelaskan bahwa perilaku prokrastinasi mencangkup dua tahapan yaitu, pertama adalah adanya dorongan untuk menunda (Srantih, 2014). Dorongan ini muncul sebagai akibat dari suasana hati negatif seperti perasaan bosan, dan kondisi negatif lain yang di alami siswa.

Kedua tahapan diatas melibatkan dua proses, yaitu prokrastinasi pasif dan aktif. Prokrastinasi pasif adalah siswa menunda tugas bahkan sama sekali tidak mengerjakan tugas. Prokrastinasi aktif adalah siswa menunda mengerjakan tugas namu siswa mencari kejelasan informasi dari tugas yang diberikan guru. Dorongan untuk menunda tersebut muncul karena siswa malas untuk berfikir dan malas untuk menghadapi kesulitan dalam mengerjakan tugas.

Dorongan ini juga bisa muncul karena siswa sedang tidak sehat atau mempunyai masalah lain seperti kondisi fisik yang tidak baik. Namun siswa tidak memiliki habatan pengaruh kondisi fisik yang tidak baik, dalam hal ini siswa melakukan penundaan karena tidak ada niat untuk mengerjakan tugas. Mungkin saja siswa merasa kurang enak badan karena kelelahan akibat aktifitas lain yang mereka kerjakan. Hal ini bisa menjadi alasan untuk membenarkan diri untuk tidak mengerjakan tugas. Siswa juga termasuk siswa yang pasif saat mengikuti kegiatan belajar di kelas, siswa malas untuk bertanya atau merespon kegiatan guru tertentu

Tidak menyukai mata pelajaran tertentu seperti Ilmu Pengetahan Alam, Matematika, Bahasa Inggris, Bahasa indonesia, Ilmu Pengetahan Sosial. Penyebab perilaku prokrastinasi akademik siswa tidak menyukai mata pelajaran dan guru tertentu. Prokrastinasi sebagai suatu pengunduran secara sengaja dan biasanya disertai dengan perasaan tidak suka untuk mengerjakan sesuatu yang harus dikerjakan (Samaedam, 2016).
Siswa melakukan perilaku prokrastinasi akademik karena disebabkan oleh perasaan tidak nyaman saat berada di lingkungan sekolah (Anisa \& Emawati, 2018). Hal ini bisa saja terjadi pada setiap siswa karena, siswa bisa saja merasa tidak nyaman dengan perlakuan guru misalnya guru kurang menghargai siswa sehingga siswa tidak nyaman saat berada di lingkungan sekolah. Reward dan punishment dari guru bisa menjadi penyebab perilaku prokrastinasi akademik dan adanya objek lain yang memberikan reward yang lebih menyenangkan dari objek yang di prokrastinasikan (Samaedam, 2016).

Terkadang suasana belajar yang kaku juga menjadi penyebab siswa merasa tegang saat proses belajar sehingga siswa tidak paham pada penjelasan yang diberikan guru. Terkadang hal seperti ini tidak di sadari oleh guru pada saat melakukan kegiatan belajar di sekolah. Walaupun sepertinya sepele tapi sangat perlu diperhatikan, karena suasana belajar memang harus menyenangkan dan santai tapi tetap fokus pada mata pelajaran yang di ajarkan di kelas.

Terpengaruh dengan teman yang tidak mengerjakan tugas juga penyebab dasar seseorang melakukan perilaku prokrastinasi (Pychyl, 2014). Perilaku prokrastinasi yang dilakukan siswa di akibatkan oleh 2 faktor internal dan juga eksternal. Faktor internal adalah karena siswa tidak memiliki niat untuk mengerjakan tugas. Faktor eksternal adalah karen siswa terpengaruh oleh teman yang tidak mengerjakan tugas. Menurut Ferrari perilaku dapat di pengaruhi oleh beberapa faktor yaitu faktor internal dan eksternal (Samaedam, 2016). Ada hubungan positif yang signifikan antara prokrastinasi akademik dan dukungan sosial teman sebaya (Pradinata \& Susilo, 2016).

Perilaku prokrastinasi yang sering siswa lakukan yaitu mencontek atau menyalin tugas teman yang sudah selesai di kerjakan. Hal ini membuktikan bahwa siswa tidak memiliki daya juang untuk mengerjakan tugasnya sehingga siswa memilih untuk mencontek atau menyalin tugas yang sudah di kerjakan membaca dan memperbaikinya. Siswa tidak memiliki kemauan untuk berusaha mengerjakan tugas yang telah guru berikan. Siswa tidak memiliki tangung jawab terhadap tugas yang menjadi tanggung jawabnya sendiri. 
Perilaku prokrastinasi akademik juga dapat dikatakan sebagai pengaruh dari motivasi belajar yang rendah. Penyebab perilaku prokrastinasi akademik yang di lakukan siswa juga disebabkan oleh motivasi belajar yang rendah. Jika siswa memiliki motivasi belajar yang tinggi maka perilaku prokrastinasi akademik di sekolah akan semakin rendah (Nitami, Dahamis \& Yusri, 2015).

Motivasi dapat menjadi suatu pengerak untuk siswa melakukan kegiatanya akademik. Tetapi jika motivasi belajar sudah rendah maka akan berpengaruh terhadap keinginan belajar siswa. Keinginan belajar inilah yang akan meningkatnya prestasi belajar siswa. Jika siswa memiliki motivasi belajar yang tinggi maka kegiatan yang berhubungan dengan akademik pun akan di ikuti dengan baik. Individu dengan motivasi akademik yang positif akan menunjukan karakteristik keinginan untuk belajar, menyukai kegiatan belajar, meyakini bahwa sekolah adalah hal yang penting (Reza, 2015). Maka semakin tinggi motivasi belajar akan menjadi berkurang atau rendah perilaku prokrastinasi akademik siswa. Besarnya motivasi yang dimiliki siswa akan mempengaruhi perilaku prokrastinasi akademik secara negatif, maka semakin tinggi motivasi yang dimiliki siswa perilaku prokrastinasi akan cenderung rendah (Reza, 2015).

\section{KESIMPULAN}

Berdasarkan hasil penelitian yang telah dilakukan peneliti, maka dapat di ketahui perilaku prokrastinasi akademik siswa yaitu penundaan memulai mengerejakan dan menyelesaikan tugas, siswa terlambat dalam mengumpulkan tugas, siswa lebih suka melakukan aktivitas lain yang menyenangkan seperti berbicara di kelas, menganggu teman di kelas, bermain game online. Penyebab perilaku prokrastinasi akademik adalah siswa tidak mengerti penjelasan tugas yang diberikan guru; siswa tidak menyukai mata pelajaran tertentu seperti Ilmu Pengetahan Alam, Matematika, Bahasa Inggris, Bahasa indonesia, Ilmu Pengetahan Sosial, terpengaruh dengan teman yang tidak mengerjakan tugas.

\section{DAFTAR PUSTAKA}

Anisa, A., \& Ernawati, E. (2018). Pengaruh Prokrastinasi Akademik Terhadap Hasil Belajar Biologi Siswa Sma Negeri Di Kota Makassar. Jurnal Biotek, 6(2), 88-95

Azar, F. S. (2013). Self Efficacy, Achievement Motivation, and Academic Procrstination as Predictors of Academic Performance. US-China Education Review, 3, 11, 847857.

Aziz, R. (2015). Model Perilaku Prokrastinasi Akademik Mahasiswa Pascasarjana. Journal of Islamic Education, 1 (2), 270-295.

Burhani. I. I. (2016) Pemaknaan Prokrastinasi Akademik Pada Mahasiswa Semester Akhir Di Universitas Muhammadiyah Surakarta. Skripsi. Universitas Muhammadiyah Surakarta

Kadi, A. P. U (2016). Hubungan Kepercayaan Diri Dan Self Regulated Learning Terhadap Prokrastinasi Akademik Pada Mahasiswa Psikologi 2013. e-Jurnal Psikolog, 4 (4), 457- 471.

Kuswandi, N. (2009). Analisis Deskriptif Faktor-Faktor Penyebab Prorastinasi Penyelesaian Skripsi pada Mahasiswa Strata Satu Fakultas Ilmu Pendidikan Universitas Negeri Semarang Angkatan 2001 dan 2002. Intuisi: Jurnal Psikologi Ilmiah, 1(1), 17-26.

Moleong, L. J. (2017). Metodologi Penelitian Kualitatif. Bandung: Remaja Rosdakarya Offset.

Munawaroh, M. L., Alhadi, S., \& Saputra, W. N. E. (2017). Tingkat Prokrastinasi Akademik Siswa Sekolah Menengah Pertama Muhammadiyah 9 Yogyakarta. Jurnal Kajian Bimbingan dan Konseling, 2 (1), 26-31.

National Association of School Psychologists. (2014). Academic Motivation : Strategies for Parents. Diakses melalui http://www.fcps.edu/LongfellowMS/pages/PTA/Academ ic\%20Motivaton\%20\%20Strategies\%20for\%20Parents. Pdf pada tanggal 14 Juli 2019 pukul 20:22 Wib.

Nitami, M., Daharnis, D., \& Yusri, Y. (2015). Hubungan Motivasi Belajar dengan Prokrastinasi Akademik Siswa. Konselor, 4(1), 1-12.

Pradinata, S. \& Susilo, J. D. (2016). Prokrastinasi Akademik dan Dukungan Sosial Teman Sebaya pada Mahasiswa Fakultas Psikologi Universitas Katolik Widya Mandala Surabaya. Jurnal Experientia, 4, 85-95.

Pychyl, T. (2014). Procrastinational: Oops, Where Did The Day Go? Diakses melalui ttp://www.psychologytoday.com/articels/201109/ procrastional-oops-where-did-the-day-go. pada tanggal 7 Juli 2019 pukul 13:22 Wib.

Ramadhan, R. P., \& Winata, H. (2016). Prokrastinasi Akademik Menurunkan Prestasi Belajar Siswa. Jurnal Pendidikan Manajemen Perkantoran, 1(1), 163-169.

Reza, I. F. (2015). Hubungan antara motivasi akademik dengan prokrastinasi akademik pada mahasiswa. Humanitis: jurnal psikologi indonesia, 12 (1), 39-44.

Rohmatun, R., \& Taufik. T (2014). Hubungan Self Efficacy Dan Pola Asuh Otoriter Dengan Prokrastinasi Akademik 
Pada Mahasiswa. Jurnal Penelitian Humaniora, 15 (1), 47-54.

Rosani, T., \& Indrawati, E. S. (2018). Hubungan Antara Pola Asuh Otoriter Dengan Prokrastinasi Akademik Pada Mahasiswa Angkatan 2013 Jurusan Fakultas Ilmu Sosial Dan Ilmu Politik Universitas Diponegoro. Empati, 7 (2), 114-119.

Samaedam, S. (2016). Hubungan Harga Diri Dan Konsep Diri Dengan Prokrastinasi Akademik Pada Siswa Kelas III Sekolah Ma'had Al-Muhammadiah Thailand Selatan. SKRIPSI, fakultas psikologi universitas islam maulana malik Ibrahim malang.

Saman, A. (2017). Analisis Prokrastinasi Akademik Mahasiswa (Studi Pada Mahasiswa Jurusan Psikologi Pendidikan Dan Bimbingan Fakultas Ilmu Pendidikan). Jurnal Kajian Psikologi Pendidikan dan Bimbingan Konseling, 3 (2), 55-62.

Santika, W. S., \& Sawitri, D. R. (2016). Self-regulated Learning Dan Prokrastinasi akademik pada siswa kelas XI SMA Negeri 2 Purwokerto. Empati, 5 (1), 44-49.

Srantih, T. (2014). Pengaruh Perfeksionisme Terhadap Prokrastinasi Akademik Pada Mahasiswa Yang Sedang Mengerjakan Skripsi Difakultas Psikologi Uin Sunan Gunung Djati Bandung. Psympathic: Jurnal ilmiah psikologi, 1 (1), 58-68.

Utomo, D. (2010). Hubungan antara pemalasan sosial dengan prokrastinasi akademik. Skripsi, Universitas Muhammadiyah, Surakarta. Diunduh dari http://etd.eprints.ums.ac.id/1034 7/1/F100060039.

Yusuf. M. (2013). Metode Penelitian Kuantitatif, Kualitatif dan Penelitian Gabungan. Jakarta: Prenadamedia Group. 